DOI:

UDC 621.771 .01

O.P. Maksimenko, Doctor of Tech. Sc., professor, head of the Department of metal processing by pressure, O.maks1940@gmail.com

A.V. Nikulin, Cand. of Tech. Sc., docent, av_nikulin@ukr.net

D.I. Loboiko, assistant, darloboyko@gmail.com.

Dniprovsk State Technical University, Kamianske.

\title{
SIMULATION THE LONGITUDINAL STABILITY OF THE ROLLING PROCESS IN A STABLE MODE
}

Further analysis of limit rolling conditions in a stable mode with clarification of the mechanism of longitudinal stability of the strip in the rolls and development of recommendations on this issue.

Estimation of longitudinal stability of the strip based on the determination of the average resulting internal longitudinal forces.

The use of a new limit condition for a stable rolling process, based on the determination of the average resultant force of plastically deformed metal, is developed and substantiated.

For the first time, the criterion for optimization of the tension regimes for the construction of energy-saving rolling technology was proposed to use the values of the average resultant longitudinal forces of plastically deformable of the strip, which allowed proving the feasibility of conducting the process at close to zero values of this force.

Using the proposed criteria can more accurately determine the limit conditions of rolling, which in turn allows further improve compression and tension modes for continuous production of strips and sheets on the conditions under which the deformation process will proceed in optimum conditions in terms of energy and longitudinal stability strips and sheets in rolls.

Key words: longitudinal stability; angle of neutral intersection; coefficient of friction; limit conditions.

Подальший аналіз граничних умов прокатування в сталому режимі з уточненням механізму поздовжньої стійкості штаби в валках і розробкою рекомендацій з даного питання.

Оиінка поздовжньої стійкості штаби на основі визначення середньої результуючої внутрішніх поздовжніх сил.

Розроблено та обгрунтовано використання нової граничної умови при сталому процесі прокатування, яка заснована на визначенні середньої результуючої сили пластично деформованого металу.

Вперше в якості критерію оптимізаиії режимів натяжіння для побудови енергозберігаючої технології прокатування запропоновано використовувати значення середньої результуючої поздовжніх сил пластично деформуємої штаби, щэо дозволило довести доиільність ведення процесу при близьких до нуля значеннях иієї сили.

Використання запропонованого критерію дозволяе більш точно визначати граничні умови прокатування, що в свою чергу дозволяє в подальшому вдосконалити режими обтиснень і натяжіннь для виробництва листів на безперервних станах, при яких проиес деформації буде протікати в оптимальних умовах з точки зору енерговитрат і поздовжньої стійкості штаби в валках.

Ключові слова: поздовжня стійкість; кут нейтрального перетину; коефіцієнт тертя; граничні умови.

\section{Problem's Formulation}

In theory from manuals the level of stability of the rolling process up to its transition to limit conditions and the appearance of partial slippage is determined by the length of the outstripping zone and in limit the neutral angle $\gamma$ is equal to zero [1-3]. The accepted limit condition is often used in theoretical studies and in practical work [4,5]. It is known that this limit condition is closely related to 
the maximum angle of capture at a steady process $\alpha_{\max }=2 f$ ( $f-$ coefficient of friction) and to the special nature of the pressure distribution along the length of the deformation zone, the pressure epure looks like a concave curve at average pressure $p_{a v}<2 k_{a v}\left(2 k_{a v}\right.$ - the average resistance of deformation of the metal in rolling). In addition, under these conditions, the longitudinal normal stresses $\sigma_{x}$ over the entire length of the contact area become tensile, although under normal condition of rolling they are compressive. For energy reasons, it is difficult to explain that, with significant plastic deformation and some friction losses, the average pressure in the deformation zone may be less. The above casts doubt on the possibility of rolling in these conditions, apparently the process should end at a smaller angle of capture.

\section{Formulation of the study purpose}

The purpose of this work is to further analyze the limit conditions of rolling in a stable mode with the refinement of the mechanism of longitudinal stability of the specimen in the work rolls and to develop recommendations on the subject.

\section{Presenting main material}

Let us make a condition of equilibrium of the selected current volume of metal in the deformation zone (Fig. 1a). When replacing the action of the roll on the strip with contact forces, and the discarded part of the roll with longitudinal internal forces (Fig. 1b), the following expression in dimensionless form will be valid:

$$
-2 \int_{\varphi}^{\alpha} \frac{p_{x}}{2 k_{a v}} \sin \varphi d \varphi R b+2 \int_{\varphi}^{\alpha} \frac{t_{x}}{2 k_{a v}} \cos \varphi d \varphi R b-\frac{\sigma_{x}}{2 k_{a v}}\left(\frac{h_{1}}{R}+\varphi^{2}\right)=0 .
$$

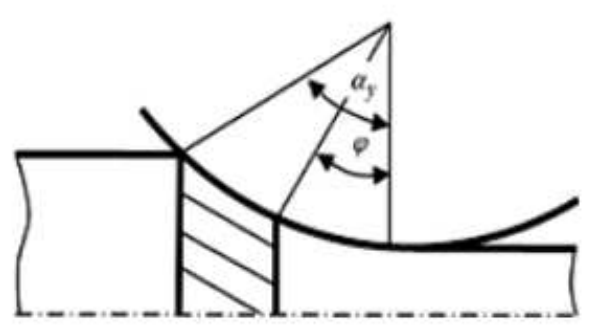

$a$

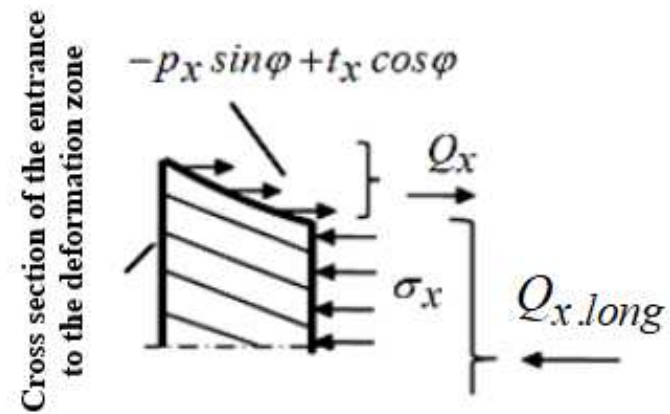

$b$

Fig. 1. To equilibrium of horizontal forces: $\mathrm{a}-$ deformation center; $\mathrm{b}-$ selected current volume of metal

Denote the sum of the current contact forces through $Q_{x . c u r .}^{*}$ and the internal through $Q_{x . l o n g}^{*}$ and further determine the average resulting values for their deformation center. The result is:

$$
\begin{gathered}
Q_{x . c u r .}^{*}-Q_{x . l o n g}^{*}=0, \\
Q_{\text {av.cur. }}^{*}=\frac{1}{\alpha} \int_{0}^{\alpha} Q_{x . c u r .}^{*} d \varphi, \\
Q_{\text {av.long }}^{*}=\frac{1}{\alpha} \int_{0}^{\alpha} Q_{x . l o n g}^{*} d \varphi,
\end{gathered}
$$

where $p_{x}$ and $t_{x}$ - contact normal and tangential stresses; $\alpha$ and $\varphi-$ the angle of capture and its current value; $h_{1}$ - the thickness of the strip at the exit of the rolls; $R$ - the radius of the rolls; $\sigma_{x}$ - longitudinal normal stresses. 
The current internal forces $Q_{x . l o n g}^{*}$, depending on the rolling conditions, can be compressed and directed opposite to the movement of the strip along the entire length of the deformation zone, or be stretched in a separate section with a corresponding direction determined by the nature of the stress $\sigma_{x}$ change. The average result of these forces $Q_{a v}^{*}$.long is an integral force of resistance, and can not play an active role in the deformation zone. It should not be conducive to the rolling process and is therefore always directed in the opposite direction to the movement of the strip. In this regard, it was assigned a negative value. At the same time, in theoretical calculations the force $Q_{a v . l o n g}^{*}$ can take positive values under certain parameters of rolling. The latter indicates that under the proposed conditions in the zone of deformation is insufficient to draw metal into the rolls of forces [see equation (2)] and additional equilibrium are required to equilibrium, which theoretically plays the role of the average resultant $Q_{a v}^{*}$.long. But as noted above, being resistance cannot accomplish this task. Therefore, if $Q_{a v \text { long }}^{*}<0$ the rolling is performed without partial slippage, then $Q_{a v \text {.long }}^{*}>0$ the process is not possible. Then the limit case of rolling:

$$
Q_{\text {av.long }}^{*}=0 \text {. }
$$

We evaluate the longitudinal stability of the rolling process for specific conditions, calculating the average resultant force $Q_{a v}^{*}$ long. In calculating this value we will proceed from the solution of the differential equation of equilibrium by T. Karman, conditions of plasticity in the model of contact friction: $t_{x}=f p_{x}$. Let the rolling be in rolls with a radius $R=100 \mathrm{~mm}$, reduction is $\Delta h=4.0 \mathrm{~mm}$, the initial thickness of the strip $h_{0}=8 \mathrm{~mm}$, and the coefficient of friction in the steady state $f$ takes consecutive values of 0,$2 ; 0,139$ and 0,1 . The results of the calculation of the contact stresses, the current longitudinal force $Q_{x . l o n g}^{*}$ and its average resultant value $Q_{a v . l o n g}^{*}$ are shown in Figs. 2.

At $\frac{\alpha}{f}=1$ (curve 1) at all sections of the deformation zone, the current force $Q_{x . c u r}^{*}$. is compressive (opposite to the movement of the strip). The average result is equal to $Q_{a v . l o n g}^{*}=-0,00946$. In this case, the process must proceed steadily without noticeable partial slippage at a large area of the lead. In conditions where $\frac{\alpha}{f}=2$ (curves 3 ) the force $Q_{x \text {.long }}^{*}$ along the entire length of the deformation zone, as noted above, is directed toward rolling, the average resultant force in this case is positive and equal $Q_{a v \text {.long }}^{*}=0,0646$. It seems to help the process, but being an internal reactive force, it cannot accomplish this task. Therefore, in rolling conditions $\frac{\alpha}{f}=2$ it is impossible. Let us analyze the third case in which $\frac{\alpha}{f}=1,44$. As can be seen, when rolling under these conditions, longitudinal tensile forces $Q_{x}^{*}$.long act on one section of the deformation zone, and compression forces on the other (curve 2, Fig. 2, c). The area of positive and negative values under curve 2 relative to the zero line is equal to each other. Therefore, the resulting internal force $Q_{a v . l o n g}^{*}$ is zero, indicating a limit rolling event. It should be noted that the new limit condition $Q_{a v . l o n g}^{*}=0$ is more stringent than the known limit condition, since it requires a higher value of the friction coefficient in the limit case. Note that when $Q_{a v . l o n g}^{*}=0$ the deformation zone remains in the area of deformation (see curve 2, Fig. 2b). This fact is confirmed by the research data given in the articles [6,7]. Thus, the authors of [7], investigating the dependence of the advance on the angle of capture of the tips, a loss of equilibrium forces in the deformation zone followed by slipping at a metal advance 
of $4.0 \%$. Under the conditions corresponding to the parameters of the test rolling $(D=210 \mathrm{~mm}$; $h_{1}=3.75 \mathrm{~mm}$; wedge-shaped specimens with three differences; $f \approx 0.26$ ), calculate the value of $Q_{a v \text {.long }}^{*}$. The results of experiments and the calculated data of the average longitudinal force are shown in Fig. 3.
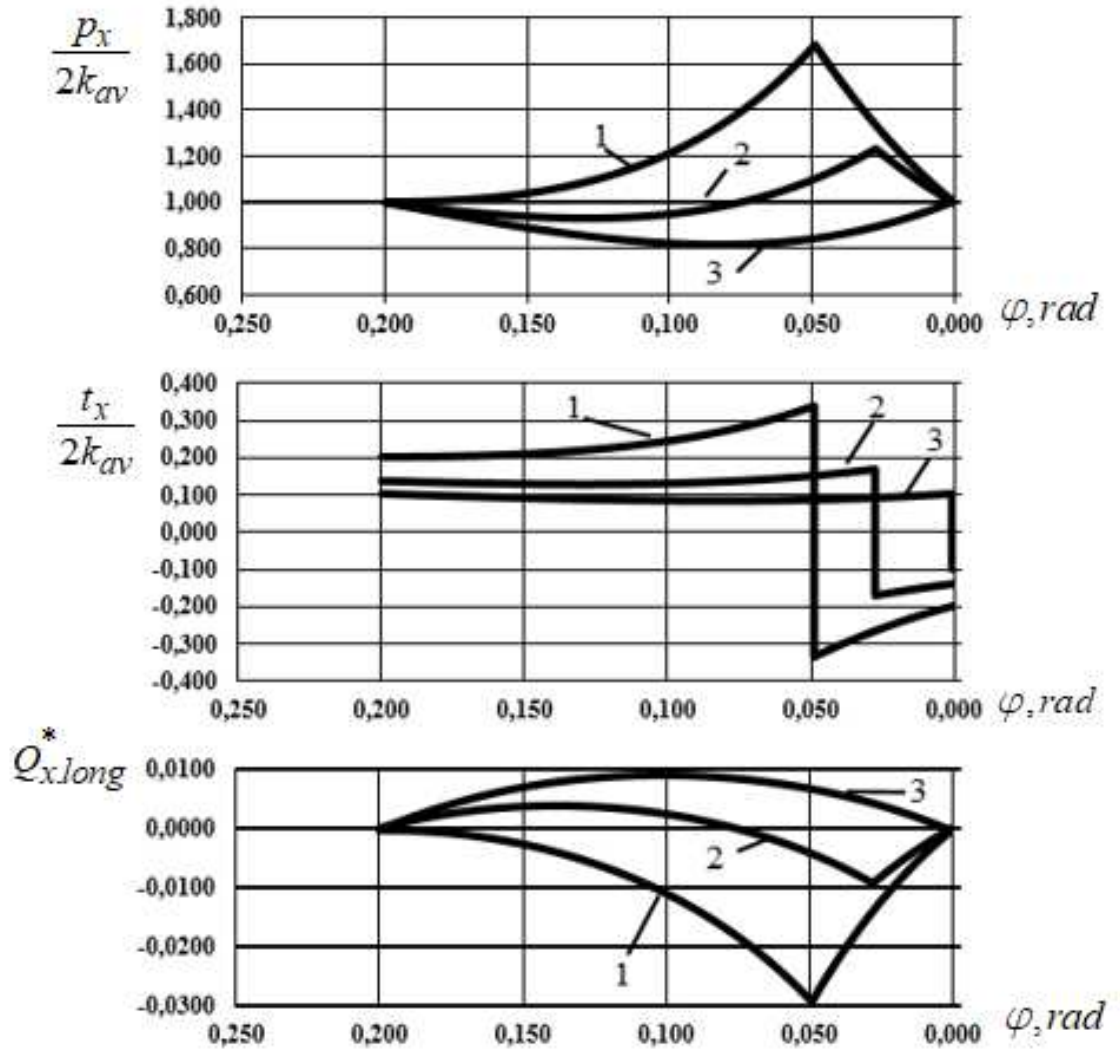

Fig. 2. Distribution of contact stresses and current longitudinal forces in the deformation zone

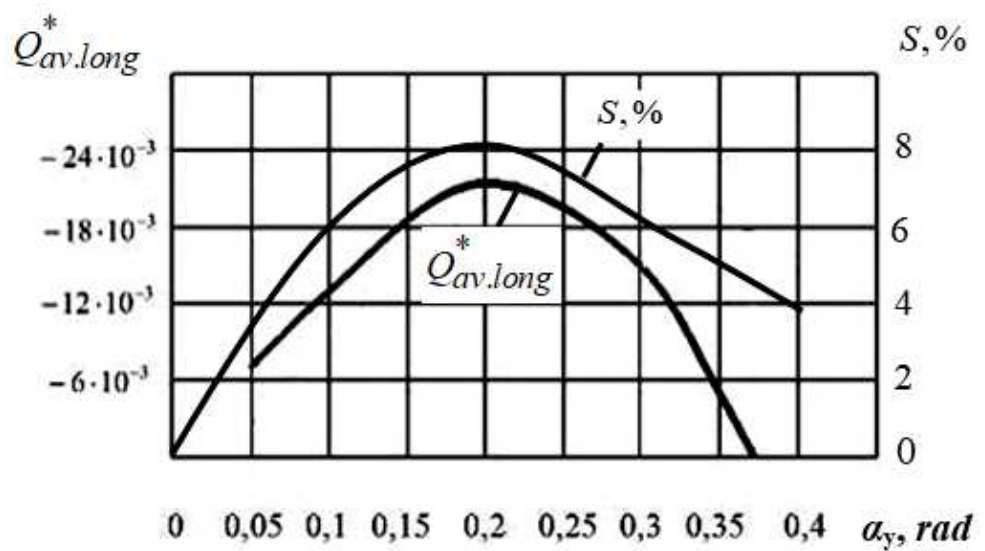

Fig. 3. Dependence of outstripping and average resultant force on the angle of capture

As can be seen, the curves $Q_{a v . l o n g}^{*}$ and $S$ the close ones are qualitatively, the maximum value of which is located in the same section. Note that the intersection, in which the outstripping is 
approximately equal $S=4 \%$, corresponds to the zero value of the average resultant force, so that it accurately reflects the limit conditions of rolling. In addition to what is outlined in fig. In Fig. 4 shows the plots of contact and longitudinal stresses, as well as showing the change in the current internal force $Q_{x . l o n g}^{*}$ when rolling with a gripping angle is equal to $\alpha=0,38 \mathrm{rad}$. The analysis of which shows that the process occurs in limit conditions with $Q_{a v . l o n g}^{*}=0$, which coincides with the experimental data of the work [7].

The range of action of the limit condition (5) obviously covers the entire spectrum in the thickness of the rolling strip. However, in the presented variant, being related to the solution of $\mathrm{T}$. Karman's equation, they can be used only when rolling thin and medium-thick strips. In our view, this limit condition can be particularly useful for the continuous rolling, with metal tension in the interstanding space.

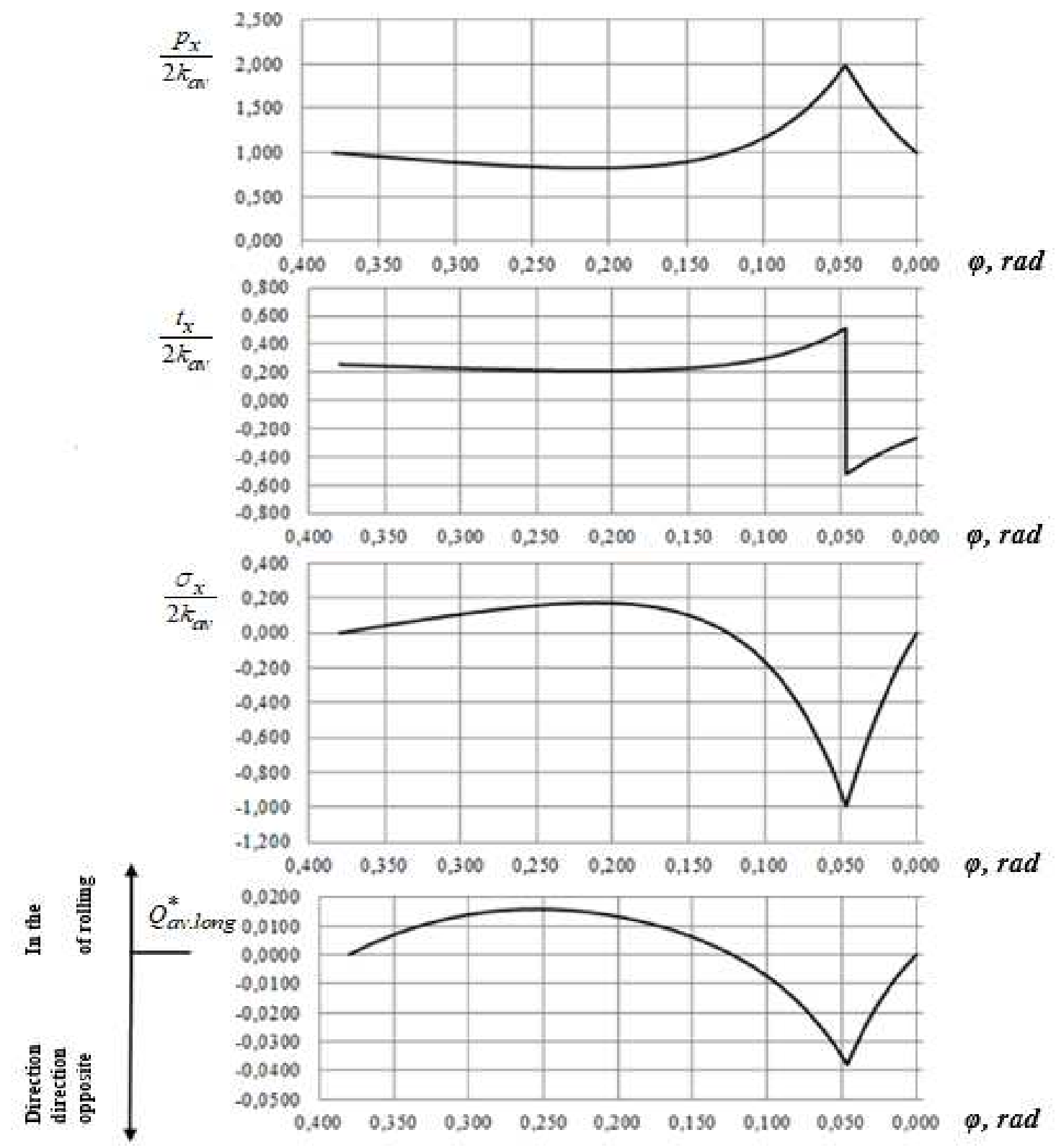

Fig. 4. Calculations of stresses and forces when rolling with $\alpha=0,38 \mathrm{rad}$ 


\section{Conclusions}

A new limit condition of the stability of rolling process has been developed and substantiated. It is based on the determination of the average resultant force of plastically deformed metal. With the negative value of this force, which is directed opposite to the movement of the specimen, the process is stability without noticeable partial slippage. If this force is equal to zero the rolling is carried out in limit conditions. With a positive average resultant force, the process is impossible. The new limit condition is more stringent than the known one. The loss of equilibrium of forces in the deformation zone with subsequent slipping can occur in the presence of advancing zone.

\section{References}

[1] Tselikov, A. I. (1962) Teoriya rascheta usiliy v prokatnykh stanakh [Theory of calculation of efforts in rolling mills]. M. : Metallurgizdat [in USSR].

[2] Grudev, A. P. (2001) Teoriya prokatki [Rolling theory]. M. : «SP Intermet Inzhiniring» [in Russia].

[3] Vasylev, Ya. D., \& Mynaev, A. A. (2010) Teoryia prodolnoi prokatky [Theory of longitudinal rolling]. Uchebnyk dlia mahystrantov VUZov. Donetsk [in Ukrainian].

[4] Vasylev, Ya. D., \& Potanovskyi, S. Y. (1988) Opredelenye uslovyi vedenyia protsessa kholodnoi prokatky tonkykh polos s mynymalnoi syloi [Determination of the conditions for conducting the process of cold rolling of thin strips with minimal force]. Yzvestyia vuzov. Chernaia metallurhyia - Proceedings of Higher Educational Institutions. Ferrous Metallurgy, 9. 68-71 [in Russia].

[5] Vasylev, Ya. D., \& Safian, M. M. (1976) Proyzvodstvo polosovoi y lystovoi staly [Production of strip and sheet steel]. K. : Vyshcha shkola [in USSR].

[6] Hrudev, A. P. (1998) Zakhvatuvaiushchaia sposobnost prokatnykh valkov [The exciting ability of the rolling rolls]. M. : «SP Yntermet Ynzhynyrynh» [in Russia].

[7] Chekmarev, A. P., Prokofev, V. I., Galitskiy, V. P. (1967). Eksperimentalnoe issledovanie maksimalnyih uglov zahvata pri ustanovivshemsya protsesse prokatki [Experimental study of maximal capture angles during steady rolling process]. Obrabotka metallov davleniem : Nauchnyie trudyi, DMetI - Metal forming: Scientific works, DMetI. M. : Metallurgiya, LII. 79-88 [in USSR].

\section{МОДЕЛЮВАННЯ ПОЗДОВЖНЬОЇ СТІЙКОСТІ ПРОЦЕСУ ПРОКАТУВАННЯ В СТАБІЛЬНОМУ РЕЖИМІ Максименко О.П., Нікулін О.В., Лобойко Д.І.}

\section{Реферат}

Метою даної роботи $є$ подальший аналіз граничних умов прокатування в стабільному режимі з уточненням механізму поздовжньої стійкості розкату в робочих валках та вироблення рекомендацій з цього питання. Діючі внутрішні сили, залежно від умов прокатування, можуть бути стискаючими і спрямовані протилежно переміщенню штаби по всій довжині зони деформації, або розтягуючими на окремій ділянці з відповідним напрямком, визначеним характером напруження. Середня результуюча цих сил $є$ інтегральною силою опору, і не може грати активну роль в зоні деформації. Вона не повинна сприяти процесу прокатки і тому завжди спрямована у зворотному до руху штаби напрямку.

Обчислюючи значення середньо інтегральної поздовжньої сили, автори виходитимуть 3 розв'язання диференціального рівняння рівноваги Т. Кармана, умов пластичності та моделі контактного тертя по Кулону. Нехай прокатування відбувається у валках радіусом 100 мм, 3 обтисненням - 4,0 мм, початковою товщиною штаби 8 мм, а коефіцієнт тертя в сталому режимі приймає послідовні значення 0,$2 ; 0,139$ та 0,1. По-перше, якщо на всіх ділянках зони деформації поздовжня сила стискаюча (напрямлена протилежно руху штаби), середній результат дорівнює -0,00946. В цьому випадку процес повинен протікати стійко без помітних частко- 
вих пробуксовок при значній зоні випередження. Якщо середня результуюча сила додатна $\mathrm{i}$ дорівнює 0,0646, тоді в цьому випадку процес неможливий. Проаналізуємо випадок, коли при прокатуванні на одній ділянці зони деформації поздовжні сили діють на розтягування, а на іншій — як сили стиску. Площі додатних і від'ємних значень понад і під кривою відносно нульової лінії дорівнюють одна одній. Тому отримана результуюча внутрішня сила дорівнює нулю, що вказує на граничну умову прокатування.

Нова гранична умова стійкості процесу прокатування грунтується на визначенні середньої результуючої сили пластично деформованого металу. При від’ємному значенні цієї сили процес $є$ стабільним. Якщо ця сила дорівнює нулю, прокатування проводиться в граничних умовах. При додатному значенні середньої результуючої сили процес неможливий. Втрата рівноваги сил у зоні деформації з подальшим ковзанням може статися при наявності зони випередження.

\section{Література}

1. Целиков А. И. Теория расчета усилий в прокатных станах. М. : Металлургиздат, 1962. 494 с.

2. Грудев А. П. Теория прокатки. М. : «СП Интермет Инжиниринг», 2001. 280 с.

3. Василев Я. Д., Минаев А. А. Теория продольной прокатки. Учебник для магистрантов ВУЗов. Донецк, 2010. 456 с.

4. Василев Я. Д., Потановский С. И. Определение условий ведения процесса холодной прокатки тонких полос с минимальной силой. Известия вузов. Черная металлургия. 1988. № 9. С. $68-71$.

5. Василев Я. Д., Сафьян М. М. Производство полосовой и листовой стали. К. : Вища школа, 1976. $192 \mathrm{c}$.

6. Грудев А. П. Захватывающая способность прокатных валков. М. : «СП Интермет Инжиниринг», 1998. $283 \mathrm{c.}$

7. Чекмарев А. П., Прокофьев В. И., Галицкий В. П. [и др.] Экспериментальное исследование максимальных углов захвата при установившемся процессе прокатки. Обработка металлов давлением : Научные труды, ДМетИ. М. : Металлургия. 1967. Вып. LII. - C. 79-88. 